Jakub Jiřiště*

\title{
Rozwój współpracy koprodukcyjnej między telewizją czechosłowacką i polską w cieniu socjalistycznego internacjonalizmu w latach 1953-1989
}

Artykuł oparty jest na badaniach i opracowaniu dostępnych, fragmentarycznie zachowanych źródeł archiwalnych i sprawozdań rocznych byłego Wydziału Stosunków z Zagranicą Telewizji Czechosłowackiej (ČST) oraz Telexportu ${ }^{1}$ (przechowywanych w Archiwum Akt Telewizji Czeskiej). Temat współpracy między dwoma krajami zostaje ujęty poprzez określenie ram instytucjonalnych, zarysowany zostaje również kontekst pozostałych stosunków międzynarodowych Telewizji Czechosłowackiej, która w większości przypadków była inicjatorem projektów koprodukcji oraz umów z Telewizją Polską. Współpraca obu instytucji rozwijała się jednak ze zmienną dynamiką i charakteryzowała się następującymi po sobie okresami rozmachu i wyhamowania kontaktów. Badany okres, od początku transmisji telewizyjnej aż do rozpadu bloku państw socjalistycznych, można podzielić na trzy umowne sinusoidy.

\section{Sinusoida pierwsza: $1953-1968$}

Telewizja Czechosłowacka (ČST) aktywnie poszukiwała możliwości współpracy z sąsiednimi państwami socjalistycznymi już kilka miesięcy po rozpoczęciu nadawania w maju 1953 roku. Również w ciągu następnych dziesięcioleci pozostała głównym inicjatorem i gwarantem ciągłej współpracy telewizji socjalistycznych, wobec której instytucje pozostałych

* Uniwersytet Karola w Pradze.

1 Telexport powstał jako oddział ds. organizacji ČST w 1964 roku w wyniku porozumienia z Ministerstwem Handlu Zagranicznego i przejął odpowiedzialność za prowadzenie niemal wszystkich operacji handlowych z zagranicą - takich jak zakup i sprzedaż programów telewizyjnych dla Czechosłowackiej Telewizji oraz wymiany z jej odpowiednikami za granicą. W późniejszych latach oddział negocjował i zajmował się organizacyjnym zapleczem międzynarodowych koprodukcji, ale dysponował także własnym zespołem filmowym, realizującym zlecenia z zewnątrz. 
krajów podchodziły w zdecydowanie mniej aktywny sposób. Nie przez przypadek to właśnie Praga została w roku 1960 centrum koordynacyjnym sieci Interwizji, mającej umacniać poczucie więzi między państwami socjalistycznymi poprzez wymianę programów oraz wspólną organizację wydarzeń telewizyjnych o charakterze sportowym, kulturalnym, politycznym, a później rozrywkowo-edukacyjnym (Interquizy). Poza zakresem w ten sposób zorganizowanej współpracy udawało się jednak rozwijać także inne formy współdziałania, przede wszystkim z inicjatywy ČST, wynikające z jej strategicznej pozycji pomiędzy trzema państwami socjalistycznymi z szybko rozwijającą się kulturą telewizyjną.

Najstarszy odnaleziony w Archiwum Akt Telewizji Czeskiej dokument dotyczący stosunków międzynarodowych podaje, że w roku 1955 funkcjonowała już obustronna współpraca Telewizji Czechosłowackiej ze Związkiem Radzieckim i NRD, a Polska i Węgry (tutaj nadawanie wciąż znajdowało się na etapie eksperymentalnym, ograniczonym do bardzo wąskiej publiczności) pozostawały z Telewizją Czechosłowacką w jednostronnym kontakcie. Oznacza to, że Telewizja Czechosłowacka jako czynnik inspirujący te stosunki oferowała wyłącznie własne programy na taśmie filmowej, nie oczekując przesyłek programów zagranicznych².

Pierwszą formą współpracy międzynarodowej pomiędzy telewizjami socjalistycznymi była więc wymiana programów, która jednak przez kilka lat pozostawała niezrównomierna. Produkcja własna filmów telewizyjnych rozwijała się powoli, a do końca lat 50 . udawało się produkować je regularnie tylko w NRD i Czechosłowacji. W pozostałych krajach, w których produkcja filmowa była sporadyczna lub nie istniała, korzystano z dystrybucji filmów oferowanych na zasadach wymiany dzięki współpracy z ośrodkami kulturalnymi poszczególnych państw. W przypadku Polski udało się prowadzić wymianę z własnych źródeł aż do roku 1963, gdy powstał film Telewizji Polskiej Lot, który po części kręcono we współpracy z ekipą Telewizji Czechosłowackiej ${ }^{3}$.

W tym samym czasie zaczęły się także pojawiać inne formy współpracy, nie tylko w ramach krajów socjalistycznych - najbardziej ożywione było przekazywanie sprawozdań informacyjnych. Liczba wymienianych nagrań informacyjnych w przypadku środkowoeuropejskich krajów so-

2 Programowa współpraca z telewizjami demokracji ludowych w roku 1956, Archiwum Akt ĆT, zespół ZS, karton 33, nr i. 294.

3 Współpraca z Telewizją Polską w roku 1963, Archiwum Akt ČT, zespół ZS, karton 12, nr i. 108. Gabriela Urbańska podaje, że nie był to film, lecz serial telewizyjny. Por. taż, Historia polskiego filmu telewizyjnego, https://www.sfp.org.pl/2016/baza_wiedzy,307,1487,0,1,Historia-polskiego-filmu-telewizyjnego.html (dostęp: 1.09.2017). 
cjalistycznych przekraczała po obu stronach sto materiałów na rok. Jeszcze przed rozpoczęciem działalności sieci Interwizji okazjonalnie organizowano pierwsze transmisje międzynarodowe, a pierwszym większym przedsięwzięciem tego rodzaju stała się współpraca ČST, TVP i DFF (Deutscher Fernsehfunk) podczas Wyścigu Pokoju w 1956 roku. Wówczas możliwe były jedynie transmisje z Berlina dzięki już wybudowanej stacji retransmisyjnej. Bezpośrednie połączenie transmisyjne między Czechosłowacją a Polską zostało uskutecznione dopiero w pierwszej połowie roku 1959. Według danych z 1956 roku, pod względem poziomu współpracy z ČST Polska znajdowała się na czwartym miejscu po ZSRR, NRD i Węgrzech, jednak pod koniec dziesięciolecia dzięki różnorodnym wspólnym działaniom znalazła się wraz z Niemcami na czołowym miej$\mathrm{scu}^{5}$. Współpraca z TVP była specyficzna i aż do końca lat 60. XX wieku zupełnie wyjątkowa, ponieważ $\mathrm{w}$ jej ramach powstawały zarodki prawdziwie koprodukcyjnych programów oraz rozwijano bliskie i regularne kontakty twórcze. Początki tej współpracy odnaleźć można w redakcjach programów dla dzieci i młodzieży praskiego i warszawskiego studia, $\mathrm{w}$ których realizowano wspólne programy - najpierw w formie wymiany całych ekip twórczych, które inscenizowały telewizyjne przedstawienia dziecięce (najczęściej lalkowe) w swoim studiu, a kilka miesięcy później realizowały je za granicą $\mathrm{w}$ formie wymiany za podobny program $\mathrm{z}$ kraju partnerskiego. Podróże reżyserów i ich dzieł na trasie Praga-Warszawa, a czasem także do Bratysławy, były oczywistą częścią corocznych planów wymiany i współpracy.

W Warszawie zaistniał $\mathrm{w}$ ten sposób początkujący reżyser praskiej redakcji dziecięcej Alexander Zapletal, wówczas jeszcze student katedry dramaturgii Wydziału Teatralnego Akademii Sztuk Performatywnych w Pradze (AMU). Po jego trzymiesięcznym pobycie w Warszawie TVP zaangażowała go w roku 1958 na długoterminową umowę rozpoczynającą się od półrocznego pobytu w warszawskiej redakcji dziecięco-młodzieżowej. W tym okresie Zapletal zrealizował także kilka oryginalnych praskich inscenizacji (Pošt'ácká pohádka i Kobližek Karela Čapka), natomiast po upływie ustalonego terminu zrealizował $\mathrm{w}$ ramach bezpłatnej

${ }_{4}$ Programowa współpraca z telewizjami demokracji ludowych w roku 1956, Archiwum Akt ĆT, zespół ZS, karton 33, nr i. 294.

${ }^{5}$ Ze wschodnioniemiecką DFF prowadzono rozmowy dotyczące realizacji programów dziecięcych i pierwszych widowisk rozrywkowych już w roku 1957. Z NRD przejęto także na początku roku 1957 pierwszy scenariusz oryginalnej sztuki telewizyjnej zagranicznego autora i zrealizowano przy jego uczestnictwie w praskim studiu telewizyjnym (była to sztuka Hansa Müncheberga Der Tod von La Morgaine). Lista odwiedzających z NRD na I kwartał 1957, Archiwum Akt ČT, zespół ZS, karton 4, nr i. 33. 
wymiany polskie programy dziecięce w Pradze ${ }^{6}$. Umowa z TVP została jednak w międzyczasie odnowiona i Alexander Zapletal pozostał w warszawskim studiu jako reżyser programów dziecięcych aż do 1959 roku ${ }^{7}$. Regularna wymiana bajek lalkowych trwała do pierwszej połowy lat 60 . XX wieku i nie ograniczała się tylko do jednej wymiany na rok.

Transmisje na żywo, które w przeciwieństwie do współpracy ČST z NRD, w przypadku kontaktów z TVP były drugoplanowe, zostały zaktywizowane przez dwa programy quizowe nadawane $\mathrm{w}$ listopadzie i grudniu 1958 roku. Jak sugerują ich tytuły - Co warszawiacy wiedza o Czechosłowacji/Co prażanie wiedza o PRL (Co vědí Varšavanéo ČSR/Co vědí Pražané o PLR) - sprawdzały wiadomości mieszkańców stolic o państwie partnerskim. Ponadto powstanie tych programów opierało się na wymianie pracowników twórczych, to znaczy, że quiz z Warszawy przygotowywali czescy dramaturgowie i odwrotnie ${ }^{8}$. Pierwszą istotniejszą inicjatywą ,"koprodukcyjną" według dokumentów działu współpracy z zagranicą ČST miała być inscenizacja opery Bohuslava Martinů Veselohra na mostě. Do jej realizacji prawdopodobnie został wysłany w roku 1959 do Warszawy czechosłowacki reżyser Přemysl Freiman, który wcześniej, jak było w zwyczaju, nakręcił ją dla czeskich widzów w ČST ${ }^{9}$.

Poza linie współpracy ustalone pod koniec lat 50. XX wieku w ciągu następnego dziesięciolecia nie wykraczano, a ich ograniczenia wręcz umacniano przez wznawiane co roku protokoły o współpracy, których podstawy, w zasadzie takie same dla wszystkich państw socjalistycznych, zmieniały się jedynie $\mathrm{w}$ minimalnym stopniu. Treść protokołów opierała się na umowach obustronnych zawartych z inicjatywy ČST po kilkuletnich rozmowach prowadzonych z komitetami radia i telewizji w latach 1963-1965. Do tego czasu wzajemne kontakty udokumentowane były ogólnymi umowami o współpracy kulturalnej i naukowej między państwami socjalistycznymi, w których tylko skrótowo i niekonkretnie wzmiankowano potrzebę współpracy między instytucjami radiowymi i telewizyjnymi. Polska była pierwszym krajem, z którego

${ }^{6}$ List Alexandra Zapletala - wniosek o przedłużenie pobytu w Polskiej Republice Ludowej, Archiwum Akt ČT, zbiór ZS, ka 13, nr i. 123.

7 W redakcji programów dziecięcych i młodzieżowych ČST Alexander Zapletal pozostał do roku 1968, kiedy wyemigrował do Republiki Federalnej Niemiec, gdzie działał jako samodzielny producent, autor i reżyser filmów animowanych i seriali.

${ }^{8}$ Materiały z zebrania kolegium Centralnego Studia Telewizji, dnia 28.09.1958 - Wspólna Czechosłowacja - polskie telewizyjne programy quizowe, Archiwum Akt ČT, zespół ZS, karton 13, nr i. 123.

9 Aktualny stan stosunków zagranicznych Telewizji Czechosłowackiej, s. 3, Archiwum Akt ČT, zespół ZS, karton 3, nr i. 19. 
komitetem udało się zawrzeć umowę dwustronną. Stało się to 27 kwietnia 1963 roku w Warszawie ${ }^{10}$.

Protokoły, skonkretyzowane przez postanowienia umowy w postaci dokładnego rocznego planu współpracy, opierały się pierwotnie na kwestiach programowych i regulowały dokładne zasady wzajemności ${ }^{11}$. $\mathrm{Z}$ powodu ich raczej formalnego i kwantytatywnego charakteru nie pozostało wiele przestrzeni na zainicjowanie bardziej kompleksowej koprodukcji, która wychodziłaby poza zwykłą wymianę pracowników i ekip oraz ich „pobyty gościnne” w studiach zagranicznych czy promocyjny cel programów. Możliwości wspólnego opracowania odpowiednich propozycji i scenariuszy były również ograniczone przez zasadę wzajemności - dotyczyła ona także przesłanych scenariuszy oryginalnych sztuk telewizyjnych, które były pierwotnie przeznaczone do przestudiowania przez dramaturgów, choć ich nieznaczna część została w końcu wykorzystana do realizacji. Protokoły nie oferowały więc przestrzeni na wspólne opracowanie literackie materiałów, a przy praktycznie nieistniejącym budżecie przeznaczonym na kontakty zagraniczne z krajami socjalistycznymi, współfinansowanie ich realizacji zastępowała właśnie zasada wzajemności, wymiany i przyjaźni. Współpraca telewizji socjalistycznych na podstawie umów nie miała mieć charakteru komercyjnego, czego rygorystycznie przestrzegano. W przypadku ČST wyraźnie hamowało to rozwój prawdziwej współpracy koprodukcyjnej - zwłaszcza w porównaniu z dynamicznie rozwijającymi się kontaktami z państwami kapitalistycznymi.

Współpraca z Polską, biorąc pod uwagę rzeczywiście zrealizowane projekty w latach 60. XX wieku, umacniała się w postaci znacznie liczniejszych inicjatyw niż w pozostałych państwach socjalistycznych - na przykład w przypadku ZSRR ograniczała się tylko do wymiany filmów i transmisji telewizyjnych $\mathrm{w}$ ramach Interwizji ${ }^{12}$ (wyjątkiem od tej stagnacji była NRD - jeśli pominąć ochłodzenie stosunków w roku 1964 w związku z problematycznym stanowiskiem niemieckich organów władzy wobec liberalizacji polityki kulturalnej w Czechosłowacji ${ }^{13}$. Tylko Telewizja Polska miała w Pradze swego stałego korespondenta ${ }^{14}$, który we współpracy z ekipami

10 Współpraca z Telewizją Polską w roku 1963, Archiwum Akt ČT, zespół ZS, karton 12 , nr i. 108.

11 Zob. np. Protokół o współpracy między telewizją ČSSR i PRL na rok 1966, Archiwum Akt ČT, zespół Ve1, karton 75, nr i. 615.

12 Raport o stosunkach zagranicznych ČST z państwami socjalistycznymi za rok 1964, Archiwum Akt ČT, zespół 78, karton 5, nr i. 40.

13 Tamże.

14 ČST otwarła ośrodek korespondencyjny w Warszawie z czteroletnim opóźnieniem - w marcu 1968 roku. 
czechosłowackimi przygotowywał reportaże dla TVP i tylko ČST i TVP regularnie przygotowywały wspólny magazyn Interwizji Prátelstoí (w latach 1963-1966) z kwartalną częstotliwością w ramach którego realizowano żywą wymianę ekip publicystycznych oraz wymianę ich reportaży ${ }^{15}$. Wyłącznie na polu kontaktów polsko-czechosłowackich zaistniała obustronnie zagwarantowana w latach 60 . XX wieku wymiana scenariuszy i reżyserów. Starania o jej rozwój zastępowały bardzo ograniczoną wymianę inscenizacji telewizyjnych ${ }^{16} \mathrm{i}$ w przybliżeniu do połowy dekady była to także jedyna rzeczywiście twórcza współpraca. Ramy programów dziecięcych przekroczyła jednak tylko w minimalnym stopniu i ograniczyła się ostatecznie do jednego wydarzenia dotyczącego oryginalnych sztuk telewizyjnych. W 1966 roku reżyser Józef Słotwiński wraz z polskim scenografem i kamerzystą opracował w bratysławskim studiu adaptację sztuki Leona Kruczkowskiego Śmierć gubernatora ${ }^{17}$. Następnie słowacki reżyser Ernest Stredňanský wyreżyserował w Warszawie adaptację telewizyjną słuchowiska radiowego Jána Soloviča Polnoc bude o pät' minut. W związku z otwartym apelem społeczno-politycznym, jaki zawierała ${ }^{18}$, stała się po emisji w ČST w roku 1962 jednym z istotniejszych dzieł zapowiadających pierwszą falę liberalizacji kulturalnej w latach 60. XX wieku' ${ }^{19}$.

$\mathrm{W}$ ocenie realizacji protokołu $\mathrm{w}$ roku 1967 pisze się, że nie przystąpiono już do realizacji ani jednego z wymienionych scenariuszy i redakcje nie występowały o reżysera gościnnego. Praktyka pobytów gościnnych została wznowiona dopiero podczas procesu konsolidacyjnego po roku 1970, kiedy do czechosłowackich studiów telewizyjnych zapraszano reżyserów z państw socjalistycznych, których politycznie zaangażowane inscenizacje pomagały łagodzić twórczość dramatyczną i tematycznie umacniać naru-

${ }^{15}$ Raport o stosunkach zagranicznych ČST z państwami socjalistycznymi za rok 1964, Archiwum Akt ČT, zespół 78, karton 5, nr i. 40.

${ }^{16}$ Nieliczne zagraniczne filmy i sztuki telewizyjne dostawały się na ekrany w latach 60. XX wieku w ramach ekskluzywnego programu Dni Telewizji Zagranicznych, których prototyp stanowiło zorganizowanie w grudniu 1966 roku Dnia Telewizji Czechosłowackiej w TVP oraz Dnia Telewizji Polskiej w ČST w następnym roku. Dopiero paraliż czechosłowackiej dramaturgii telewizyjnej po inwazji w sierpniu 1968 roku był przyczyną silnego zainteresowania (także w związku z planowanym uruchomieniem drugiego programu) produkcją zagraniczna, uzyskiwaną w ramach państw socjalistycznych przez wymianę komisji kwalifikacyjnych.

${ }^{17} \mathrm{~W}$ poprzednim roku scenariusz zrealizował w TVP reżyser Adam Hanuszkiewicz.

18 Inscenizacja z zapałem publicystyki, której w aktualnym programie ČST brakowało, poszukuje bezpośredniej odpowiedzialności starego mężczyzny za wypadek kolejowy i jako winowajcę przedstawia zdehumanizowany mechanizm biurokracji i obojętność systemu.

19 Oświadczenie w sprawie listu ambasadora ČSSR w Polsce, Archiwum Akt ČT, zespół ZS, karton 12, nr i. 109. 
szone więzi ${ }^{20}$. Do tego czasu $\mathrm{w}$ ramach wymiany przyjęto i zrealizowano jeden oryginalny scenariusz sztuki telewizyjnej polskiego autora ${ }^{21}$ - adaptację powieści Tadeusza Brezy Urząd scenarzystki Krystyny Nastulanki, który po raz pierwszy zrealizowano w roku $1963 \mathrm{w}$ TVP, a po czeskim „remake'u" w roku 1969 jako film telewizyjny nakręcił go Janusz Majewski. Tekst ten w znacznej mierze politycznie krytykował niejasne stosunki w kurii papieskiej, a błędny krąg życia emigrantów w ciekawy sposób zderzył się ze styczniowymi wydarzeniami politycznymi w Czechosłowacji, które rozpoczęły liberalny okres Praskiej Wiosny. Czołowy krytyk telewizyjny Jiř́ Lederer wspomniał, że włączenie inscenizacji Urzędu do programu w okresie zmiany klimatu politycznego nie było niewłaściwą decyzją dramaturgów, lecz „przeciwnie, z pewnością chcieli oni sprowokować do zastanowienia nad trudnym losem jednostki w skomplikowanym mechanizmie społecznym”. Uważał Urząd za jedno z wyjątkowych dzieł, „,które są w stanie wpłynać myślowo i uczuciowo na kierunek, który odpowiada duchowi naszych czasów, który odpowiada stanowi myśli widzów" 22 .

Coraz bardziej ograniczone stosunki ČST z państwami socjalistycznymi po roku 1965 kontrastowały z bardziej ożywionymi działaniami w krajach zachodnich wynikającymi z mniej odgórnej i normatywnej formy kontaktów. Nawiązanie stosunków handlowych z państwami kapitalistycznymi umożliwiało już w tym czasie realizację wspólnych ambitnych projektów, za którymi skromne koprodukcje państw socjalistycznych pozostawały w tyle ${ }^{23}$. Najwymowniej świadczą o tym liczby dotyczące reprezentacji koprodukcji w drugiej połowie lat 60. XX wieku. W przypadku państw socjalistycznych w latach 1966 i 1967 zrealizowano

${ }^{20}$ Na przykład główną inscenizację ČST na 50. rocznicę powstania ZSRR Zrození hvězdy (1972), uchwytującą epizod z życia Lenina, zrealizował zaproszony radziecki reżyser telewizyjny Oleg Lebiediew.

${ }^{21}$ W roku 1967 na ekrany wprowadzono dwie adaptacje tekstów współczesnych polskich autorów - rozprawa na temat dogmatyzmu na tle szaleństwa hiszpańskiej inkwizycji Noc bez úsvitu na motywach powieści Jerzego Andrzejewskiego Ciemności kryja ziemię w reżyserii Antonína Moskalyka, której nadawanie zostało po roku 1968 zakazane, oraz sztuka telewizyjna według opowiadania sci-fi Stanisława Lema Wierny robot w reżyserii Jana Matějovskiego (w TVP zaadoptowana przez Janusza Majewskiego w roku 1961). To ciekawe, że sztuki te, zaadaptowane przez czeskich autorów i zrealizowane przez czeskich reżyserów w praskim studiu telewizyjnym, były nieodłączną częścią list polskich filmów artystycznych emitowanych w ČST i wykazywanej „wymiany kulturalnej”.

${ }^{22}$ Jiří Lederer, Rubryka telewizyjna, „Filmové a televizní noviny 2” 24.01.1968, nr 2, s. 2.

${ }^{23}$ W drugiej połowie lat 60. XX wieku we współpracy z RFN i Francją nakręcono serię telewizyjnych filmów widowiskowych - np. filmową adaptację powieści Verne'a Sekret Wilhelma Storitza (1967), kolorową adaptację opowiadania Karela Čapka Spravedlnost pro Selvina (1968) oraz pierwszą serię serialu rodzinnego Pan Tau (1969). 
po jednej, a w kolejnych dwóch latach nie zrealizowano żadnej koprodukcji, zaś z państwami kapitalistycznymi w roku 1966 zrealizowano 8 koprodukcji, a w ciągu kolejnych trzech lat - 10 i więcej ${ }^{24}$. Zainteresowanie zachodnich partnerów wzbudzone przez sukcesy czechosłowackich filmów i rewii telewizyjnych na festiwalach międzynarodowych wyraźnie odsunęło współpracę z państwami socjalistycznymi na dalszy plan. Dzięki komercyjnej podstawie koprodukcje z silnymi partnerami znacznie obniżały koszty produkcji filmów telewizyjnych, w większości przypadków umożliwiały uzyskanie deficytowych materiałów kolorowych i przede wszystkim oznaczały dla ČST zysk dewizowy, niezbędny do rozwoju technologicznego. Coraz większe znaczenie uzyskiwały także programy produkowane na zamówienie, w których wszystkie koszty pokrywał partner zagraniczny $w$ ramach wymiany za realizację przez najatrakcyjniejszy dla siebie zespół twórczy i autorski ${ }^{25}$.

\section{Sinusoida druga: 1970-1975}

Dopiero rok 1970 dzięki nowym dyrektywom przyniósł zasadniczy zwrot i ożywienie coraz bierniejszych kontaktów z krajami socjalistycznymi, pogorszonych wcześniej dodatkowo przez kilkumiesięczną izolację ČST sparaliżowaną po wydarzeniach sierpnia 1968. Istotnym wymiarem przebiegającej konsolidacji programu ČST, rozpoczętej od wymiany kierownictwa jesienią 1969 roku, stał się proces reintegracji Czechosłowacji z obozem socjalistycznym. Nowe protokoły o współpracy w roku 1970 wyraźnie rozszerzyły potencjalne możliwości dla powstawania pełnowartościowych koprodukcji zorientowanych na dotąd pomijane programy dramatyczne ${ }^{26}$. W rozmowach pośredniczyła organizacja Telexport (w tym czasie nie posiadała jeszcze odpowiednika po polskiej stronie) reprezentująca Telewizję Czechosłowacką. Spełniała ona wszystkie zadania polegające na przygotowaniu, organizacji i realizacji kontaktów międzynarodowych w zakresie komercyjnym i państwowym. Dysponowała grupą produkcyjna, która gromadziła projekty poszczególnych redakcji i oferowała je potencjalnym koproducentom - teraz także tym z krajów socjalistycznych ${ }^{27}$.

${ }^{24}$ Raport Telexportu za rok 1971, Archiwum Akt ČT, zbiór ZS, karton 170, nr i. 997.

${ }^{25}$ Tamże.

26 Protokoły robocze o współpracy między telewizjami socjalistycznymi na rok 1970, Archiwum Akt ČT, zespół Ve1, karton 26.

${ }^{27}$ Raport Telexportu za rok 1970, Archiwum Akt ČT, zespół ZS, karton 170, nr i. 996. 
Jeszcze w roku 1970 Telewizja Czechosłowacka zaoferowała TVP projekt serialu przygodowego Łuk tęczy (Duhový luk), który został przyjęty podczas rozmów w Warszawie w trzecim kwartale i rozpoczęto nad nim prace literackie. Była to pragmatyczna, jednostronna inicjatywa. Dramaturgicznie i scenariuszowo film powstawał w rękach praskich twórców (propozycja i scenariusz były dziełem początkującego autora Karela Valtery), a ekipa realizacyjna składała się wyłącznie z czeskich pracowników (reżyserię powierzono Josefowi Maše, który mógł wykorzystać doświadczenia z realizacji filmów dla wschodnioniemieckiej DEFY), zdjęcia powstały na zamówienie w Studiu Filmowym Barrandov. Polskim wkładem był tylko udział w kosztach, zaangażowanie odtwórców polskich postaci i zorganizowanie plenerów.

W archiwum ČST brak niestety akt lub umowy koprodukcyjnej dotyczącej programu, dlatego nie było możliwe ustalenie szczegółów rozmów czy konkretniejszych danych dotyczących tej koprodukcji. Zachował się tylko krótki dokument z rozmów prowadzonych w Warszawie we wrześniu 1972 roku, podczas których ustalono polski udział w zyskach i przyjęto decyzję, że prawami handlowymi do serialu będzie dysponować Telexport, a nie spółka Film Polski (pośrednicząca w sprzedaży produkcji filmowej TVP), która wcześniej prowadziła negocjacje na ich temat ${ }^{28}$.Zdjęcia do serialu rozpoczęły się po rocznych przygotowaniach i przebiegały w roku 1972, zaś film wszedł na ekrany w następnym roku. Prace nad scenariuszem trzynastu odcinków poprzedzało zawarcie umowy z polską strona, a serial od początku realizowany był $\mathrm{w}$ ramach retoryki integracyjnej kontynuowanej przez autora. To ona niewątpliwie wpłynęła na decyzję, że atrakcyjnym i nieustraszonym głównym bohaterem będzie polski goprowiec, w którego rolę wcielił się popularny wśród Czechów aktor Stanisław Mikulski (który przed emisją serialu wielokrotnie pojawiał się na łamach pisma „Československá televize”), oraz na konstrukcję oczywistego związku miłosnego między nim, Adamem a Ewą, samotną czeską lekarką. Zasadniczą rolę odegrało jednak samo miejsce akcji - granica reprezentowana przez fizyczną przeszkodę w postaci tatrzańskiego wąwozu, który wymaga wspólnego działania, ofiarnej pomocy i solidarności, a także jest właściwą przestrzenią do przedstawienia na jej tle charakterystystyki wspólnego wroga. Intruz naruszający porządek przygranicznej symbiozy nie jest Czechem/Słowakiem ani Polakiem, lecz mordercą przychodzącym z innej przestrzeni i z innych czasów (obcokrajowiec powiązany ze zbrodniami wojennymi niemieckich

${ }^{28}$ Raport z delegacji handlowej Ing. Vrabca i J. Pospíšilovej do Warszawy, która odbyła się w dniach 11-15 września 1972, Archiwum Akt ČT, zespół ZS, karton 164, nr i. 952. 
okupantów). Łączy postaci obu narodów we wspólnym interesie - raz na zawsze rozliczyć się z mroczną, narzuconą przeszłością oraz umocnić spokój na wspólnej granicy.

Pierwsze słowa scenariusza Valtery wymownie oddają ideologię fabuły zbudowanej na podstawie elementów mitu: „To jest historia ludzi wśród wiecznych gór. Przez środek wąwozu przebiega granica. A ludzie po obu stronach są do siebie podobni, tak jak podobne są strome zbocza gór - gdy w Polsce pada, u nas zwykle też pada, gdy schodzi lawina, po obu stronach ciosają krzyże, a gdy świeci słońce, podnoszą głowy z uśmiechem na twarzach..."29.

Warunki dla powstania kolejnej równie szerokiej koprodukcji były na początku lat 70. XX wieku sprzyjające. ČST prowadziła ze stroną polską rozmowy na temat możliwości realizacji serialu telewizyjnego Przygody dobrego wojaka Szwejka ${ }^{30}$, a TVP zaoferowała projekt trzynastoodcinkowego serialu Janosi $k^{31}$. Z nieznanych powodów w obu przypadkach do realizacji nie doszło - adaptacja Szwejka nie powstała, a serial widowiskowy Janosik w reżyserii Jerzego Passendorfera został ostatecznie nakręcony tylko w polskiej produkcji. Jedyną zrealizowaną współpracą w ramach emisji dramatycznej była adaptacja telewizyjna sztuki Karela Čapka Matka, którą w roku 1972 w TVP opracował czołowy reżyser czechosłowacki František Filip. Inscenizacja została pokazana na ekranach w grudniu 1972 roku $^{32}$.

Po długich negocjacjach udało się natomiast zawrzeć umowę koprodukcyjną słowackiego Telexportu z telewizją węgierską i w roku 1973 rozpoczęto zdjęcia do serialu historycznego Vivat Beňovský!, którego wymagania techniczne znacznie przerosły jakiekolwiek działania na polu współpracy międzynarodowej w tym okresie ${ }^{33}$. Poza liczną obsadą aktorską węgierscy twórcy uczestniczyli w nim w bardziej znaczący sposób, choć wciąż w marginalnych rolach (charakteryzacja, kostiumy, asystent reżysera), jednak z tematycznego czy ideowego punktu widzenia ich współpraca w odróżnieniu od Łuku tęczy nie była tak istotna, jeśli chodzi o projekt i scenariusz. Większą wagę miał raczej pragmatyzm realizacji wykorzystywany w kontaktach z firmami zachodnioeuropejskimi, który umożliwił realizację widowiskowego serialu historycznego o słowackim

29 Alena Nehodová, Duhový Luk, „Československá televize” 1973, nr 17, s. 8.

30 Protokół o współpracy w dziedzinie telewizji między Komitetem do Spraw Radia i Telewizji „Polskie Radio i Telewizja” a Telewizją Czechosłowacką na rok 1974, Archiwum Akt ČT, zespół ZS, karton 200, nr i. 1125.

${ }^{31}$ Raport Telexportu za rok 1971, Archiwum Akt ČT, zespół ZS, karton 170, nr i. 997.

32 Sprawozdanie o realizacji protokołu i współpracy między ČST a TVP w I kwartale 1972, Archiwum Akt ČT, zespół ZS, karton 97, nr i. 456.

${ }_{33}$ Raport Telexportu za rok 1973, Archiwum Akt ČT, zespół ZS, karton 140, nr i. 785. 
kolonizatorze z uzasadnieniem co najwyżej we wspólnej roli historii narodów w granicach Królestwa Węgier.

Raport Telexportu z roku 1972 zwraca jednak uwagę na powolny i niepewny rozwój innych podobnych kontaktów. Także w kolejnych latach wytyka się w ocenach niewystarczającą współpracę z redakcjami, w których planach tematycznych brak propozycji zakładających lub stwarzających możliwość zwrócenia się do partnerów zagranicznych ${ }^{34}$. Rok później Telexport stwierdził w podsumowaniu, że wszelkie dalsze inicjatywy dotyczące koprodukcji z krajami obozu socjalistycznego spotkały się z brakiem zainteresowania, innymi słowy, telewizje zagraniczne nie odpowiedziały na kilka przesłanych propozycji ${ }^{35}$. Starania o integrację $\mathrm{w}$ formie pełnowartościowych projektów koprodukcyjnych legły w gruzach już w roku 1974, gdy jedyną jej formą była regularna produkcja zaangażowanych politycznie filmów i cykli dokumentalnych dla radzieckiej agencji informacyjnej APN (także z tendencją spadkową) i według Telexportu "nie udało się stworzyć konkretnych założeń dla przyszłych koprodukcji i zamówień”, a „zakres koprodukcji z krajami obozu socjalistycznego nie odpowiadał wzajemnym potrzebom i możliwościom"36. Telexport obwiniał nie tylko brak inicjatywy dramaturgów, lecz także kierownictwo telewizji, które nie prowadziło rozmów o możliwości wspólnej produkcji podczas kolegiów, pogłębiając w ten sposób palący brak inicjatyw i paraliż działalności Telexportu w dziedzinie koprodukcji zamówień. Odcisnęła się na nim również podupadająca komunikacja z producentami zachodnimi i utrata wieloletnich partnerów ${ }^{37}$.

\section{Sinusoida trzecia: $1976-1989$}

Choć w drugiej połowie lat 70. XX wieku zaczęto interesować się niewystarczająca aktywnością dramaturgii, a współpraca koprodukcyjna z inicjatywy ČST zaczęła być powoli wznawiana, także w tym czasie były to

${ }^{34}$ Raport Telexportu za rok 1972, Archiwum Akt ČT, zespół ZS, karton 33, nr i. 292.

${ }_{35}$ Raport Telexportu za rok 1973, Archiwum Akt ČT, zespół ZS, karton 140, nr i. 785.

36 Raport Telexportu za rok 1974, Archiwum Akt ČT, varia.

37 Po ustaniu koprodukcji z państwami kapitalistycznymi w związku z dyrektywą niepodporządkowywania zysków dewizowych ustępstwom ideologicznym i gustom partnera, doszło do ich tymczasowej minimalizacji przez obniżenie dotacji państwowych dla zachodnich organizacji telewizyjnych. Ten krok wyraźnie odcisnął się na wspólnej produkcji i wpłynął na znaczny spadek ich zainteresowania koprodukcją w formie uczestnictwa materiałowego i finansowego. Nowe oferty zakładały, że więcej stacji telewizyjnych wyprodukuje samodzielnie program na ustalony temat, a serial zostanie następnie wymieniony do emisji, co było dla ČST dewizowo nieinteresującą współpracą. Tamże. 
w krajach socjalistycznych tylko jednorazowe wydarzenia i wiele z zaoferowanych projektów dramaturgicznych zakończyło się na etapie zawarcia umów wstępnych. W latach 1976 i 1977 w związku z problemami organizacyjnymi upadło jednocześnie kilka prób nawiązania współpracy twórczej z NRD (prowadzono bezowocne rozmowy o trzech sztukach telewizyjnych, serialu i operze telewizyjnej), przez co definitywnie zamknęła się droga do wspólnej produkcji programów dramatycznych, choć NRD jako jedyne państwo aktywnie odbierało produkcję serialową ČST i regularnie pokazywało czechosłowackich artystów w swoich programach widowiskowych i muzycznych ${ }^{38}$. W Polsce także można było w tym okresie zaobserwować korzystne ożywienie stagnujących dotąd kontaktów. Dzięki współpracy redakcji rozrywkowych powstały dwa wspólne programy (Nad Dunajem a Vislou, Beriete si tu prítomnú Bratislavu dobrovolne?), które położyły podwaliny pod długotrwałe powiązanie bratysławskiego studia telewizyjnego $\mathrm{z}$ regionalnymi studiami w Polsce, przede wszystkim z krakowskim, z którym uzgodniono też wymianę pracowników programowych ${ }^{39}$. Powróciło zainteresowanie pobytami reżyserskimi, do których udało się nawiązać zwłaszcza na Węgrzech, gdzie dwie udane inscenizacje wyreżyserował Antonín Moskalyk, a także koprodukcjami w obszarze programów muzycznych. Pomimo intensywnych rozmów z TVP nie doszło do definitywnej akceptacji zaoferowanych jej projektów - połączenia baletu i pantomimy w programie muzycznym Wierchy i do rozrywkowego programu muzycznego Nad forte-piano ${ }^{40}$.

Współpraca koprodukcyjna z państwami socjalistycznymi ustabilizowała się w formie współpracy wielostronnej przy programach rozrywkowo-muzycznych i konkursach, wspólnie realizowanych koncertach i filmach dokumentalnych na wspólne tematy (Węgry, ZSRR) oraz skromnych programach, w których brały udział redakcje dziecięce i młodzieżowe (Bułgaria, NRD). Zainteresowanie kontynuacją kontaktów twórczych z Polska, wykraczających poza te standardy, potwierdzają starania o realizację znacznie ambitniejszego dzieła - trzynastoodcinkowego serialu przygodowego dla młodzieży Długi biały ślad (Dlouhá bílá stopa, reż. Petr Tuček, 1982).

${ }_{38}$ Raport o stosunkach zagranicznych ČST za rok 1976, Archiwum Akt ČT, zespół ZS, karton 169, nr i. 989; Raport o stosunkach zagranicznych ČST za rok 1977, Archiwum Akt ČT, zespół ZS, karton 169, nr i. 988.

39 Raport o stosunkach zagranicznych ČST za rok 1976, Archiwum Akt ČT, zespół ZS, karton 169, nr i. 989; Raport o stosunkach zagranicznych ČST za rok 1978, Archiwum Akt ČT, zespół ZS, karton 169, nr i. 987.

40 Raport o stosunkach zagranicznych ČST za rok 1976, Archiwum Akt ČT, zespół ZS, karton 169, nr i. 989. 
Podobnie jak w przypadku Łuku tęczy głównym motorem napędowym bliskiej i oczywistej relacji między postaciami pochodzącymi z dwóch narodów stają się nieprzewidywalne warunki panujące w górach pogranicza, tym razem Karkonoszy, gdzie dzieci i dorośli z obu stron granicy wspólnymi siłami rozwiązują problemy wywołane przez lawinę, wichurę czy przemytników. Według eksplikacji dramaturgicznej autorzy w tym otoczeniu „rozgrywają losy trzech czeskich chłopców i polskiej dziewczyny, którzy podczas wielu zajmujących i wesołych przygód poznają cenę przyjaźni i solidarności między ludźmi i narodami, nabierając aktywnego, konstruktywnego stosunku do życia" ${ }^{41}$.

Choć znaczenie i udział polskich postaci w porównaniu z Łukiem tęczy są nieistotne z punktu widzenia fabuły (z wyjątkiem Jadwigi i jej ojca), a środek ciężkości intrygi usytuowano po czeskiej stronie gór, treść umowy koprodukcyjnej świadczy tym razem o chęci osiągnięcia bardziej zrównoważonej współpracy - jednak nie z twórczego punktu widzenia. Serial był również dziełem czeskich autorów, choć prace dramaturgiczne przebiegały zarówno $\mathrm{w}$ redakcji dziecięcej i młodzieżowej ČST oraz w formie konsultacji z Centralną Wytwórnią Programów i Filmów Telewizyjnych POLTEL ${ }^{42}$. Najważniejsze pozycje w ekipie zajmowali czescy pracownicy ${ }^{43}$, polska strona gwarantowała własną ekipę z kierownikiem produkcji i scenografii dla scen kręconych w PRL, charakteryzatorów, asystentów kamery i przede wszystkim kompletne nagłośnienie włącznie z oryginalną muzyką i postsynchronizacją ${ }^{44}$. Starania o zrównoważenie współpracy przejawiały się zwłaszcza w pozostawieniu czeskiej stronie wszelkich przygotowań produkcyjnych, które kompensowały kompletne prace laboratoryjne w TVP, oraz w podziale i ostatecznym wyrównaniu wszelkich kosztów produkcyjnych po $50 \%{ }^{45}$.

${ }^{41}$ Dokumenty dramaturgiczne do programu Długi biały ślad przyjęte dnia 18.06.1979, Archiwum Akt ČT, zbiór Red, karton 247, nr i. 1728.

${ }^{42}$ Umowa koprodukcyjna między ČST Telexport a Telewizją Polską - przedsiębiorstwo handlu zagranicznego POLTEL. Archiwum Akt ČT, zespół Red, karton 383, nr i. 2871.

${ }^{43}$ Reżyserem serialu miał być pierwotnie początkujący twórca inscenizacji dla dzieci i młodzieży, Jiří Adamec, jednak jeszcze przed podpisaniem umowy koprodukcyjnej został zastąpiony przez doświadczonego Petera Tučka, który zrealizował wcześniej w ČST kilka seriali. Projekt umowy koprodukcyjnej - serial Długi biały ślad, Archiwum Akt ČT, zespół Red, karton 247, nr i. 1728.

${ }^{44}$ Załącznik do umowy koprodukcyjnej między Telewizją Polską PHZ POLTEL a Čs. Telexportem Praha o zdjęciach do serialu Długi biały ślad, Archiwum Akt ČT, zespół Red, karton 383, nr i. 2871.

${ }^{45}$ Umowa koprodukcyjna między ČST Telexport a Telewizją Polską - przedsiębiorstwo handlu zagranicznego POLTEL, Archiwum Akt ČT, zespół Red, karton 383, nr i. 2871. 
Według umowy koprodukcyjnej zawartej w grudniu 1979 roku pierwszy dzień zdjęć zaplanowano na luty 1980, a kopia gotowa do emisji miała zostać oddana najpóźniej we wrześniu 1981. Jak się jednak okazało, w odróżnieniu od szybko rosnącej liczby koprodukcyjnych seriali rodzinnych z RFN, podobna produkcja w ramach obozu socjalistycznego oznaczała znacznie bardziej skomplikowane przedsięwzięcie niż zakładano - przy czym dużą rolę odegrały także nieprzewidziane okoliczności polityczne.

Rozmowy koprodukcyjne rozpoczęto w roku 1976 i w tym samym roku projekt serialu został przyjęty. Na ekrany wszedł jednak dopiero po sześciu latach, co oznacza dwukrotnie dłuższy czas realizacji niż w przypadku projektu serialowego podobnego formatu realizowanego wówczas z zachodnim partnerem. Pierwsze komplikacje spowodowało uzależnienie ČST od wydolności i budżetu studiów filmowych. Po polskiej stronie podobne kłopoty rozwiązano w roku 1974 przez stworzenie Zakładu Produkcji Filmów Telewizyjnych POLTEL niezależnego od pozostałych studiów filmowych i organizacyjnie podporządkowanego TVP ${ }^{46}$. W związku z nadmiarem zleceń w Studiu Filmowym Barrandov serial Długi biały ślad był przygotowywany $\mathrm{w}$ skromniejszych warunkach zakładu produkcji filmowej Krátký film Praha, specjalizującego się w filmach dokumentalnych i animowanych. Poza tym, że Krátký film spotkał się ze strony Studia Filmowego Barrandov z odmową udzielenia wymaganej obsady na niemal roczne zdjęcia ${ }^{47}$, powstała inna duża przeszkoda. Żadna z instytucji nie była przygotowana na wysokie koszty personalne dla ekipy filmowej, które wzrosły ze względu na konieczność współpracy z partnerem zagranicznym i trudne zdjęcia $\mathrm{z}$ dziećmi w plenerach górskich ${ }^{48}$. Krátký film został zmuszony do zwrócenia się do Państwowej Komisji Planowania, której podlegał budżetowo, o przyznanie dodatkowych środków w wysokości miliona koron na zdjęcia zaplanowane na rok 1980. Po dwukrotnym odłożeniu terminu zdjęć pozytywną decyzję ostatecznie zatwierdzono ${ }^{49}$.

Gdy tylko rozwiązano problem finansowy, powstały trudności po stronie TVP, która w związku z komplikującą się sytuacją polityczną w Polsce została zmuszona do kompletnej reorganizacji planu produkcji - $\mathrm{z}$ tego

${ }^{46}$ Dorota Ostrowska, Małgorzata Radkiewicz, Costume dramas: cine-televisual alliances in the socialist and post-socialist Poland, [w:] European Cinemas in the Television Age, red. Dorota Ostrowska, Graham Roberts, Edinburgh University Press, Edinburgh 2007, s. 108.

${ }^{47}$ List Františka Kopeckiego (Krátký film) do Jaroslavy Kulišovej (ČST) z dnia 25.01.1980, Archiwum Akt ČT, zespół Red, karton 247, nr i. 1728.

${ }^{48}$ List Jaroslavy Krulišovej do sekretariatu dyrektora Vondry z dnia 31.01.1980, Archiwum Akt ČT, zespół Red, karton 247, nr i. 1728.

${ }^{49}$ List sekretarza ekonomicznego ČST Petra Berana do Czeskiej Komisji Planowania z dnia 4.11.1980, Archiwum Akt ČT, zespół Red, karton 247, nr i. 1728. 
powodu w czerwcu 1980 roku dalekopisem oznajmiła, że jest zmuszona do przerwania realizacji serialu. Na tę wiadomość ČST i Krátký film zwołały zebranie, podczas którego poszukiwały rozwiązania, aby lata przygotowań nie poszły na marne. Reprezentant telewizji proponował wznowienie prac we wrześniu, aby można było rozpocząć zimowe zdjęcia na początku roku 1981 - do tego czasu proponował zdjęcia do innego filmu z tą samą ekipą filmowa aby jej nie rozwiązywać (Tajemství d'áblovy kap$s y)^{50}$. Przedstawiciel reprezentujący Krátký film był zaś za wstrzymaniem wszelkich prac, a to z tego powodu, że wyjątkowe zatwierdzenie kosztów personalnych ważne było tylko na rok 1980. Sugerował zakończenie współpracy z TVP i rozpoczęcie rozmów z Filmem Polskim o świadczeniu usług dla czeskiej ekipy filmowej podczas zdjęć w zredukowanych polskich plenerach (to jest tylko na wybrzeżu w okolicach Sopotu) ${ }^{51}$.

Decyzję o przyszłości projektu odkładano aż do jesieni 1980 roku, gdy ČST wznowiła rozmowy z TVP i wysłała do Warszawy delegację, która miała wynegocjować zmiany w pierwotnej umowie koprodukcyjnej. Według raportu z podroży służbowej polska strona była bardzo skłonna do rozmów i zaskoczyło ją kilkumiesięczne milczenie ze strony ČST prowadzące do przypuszczenia, że po anulowaniu już drugiego terminu zdjęć ČST obraziła się i zerwała kontakt. Podjęto wspólne starania, aby bezzwłocznie rozpocząć prace i rekonesansy, konieczne było także znalezienie nowej obsady ról dziecięcych ${ }^{52}$.

Pierwszy dzień zdjęć zaplanowano na 15 lutego 1981 roku, jednak niemal od razu nowej umowie zaczęły zagrażać nierozwiązane uprzednio problemy między czechosłowackimi koproducentami, ponieważ Krátký film nie uwzględnił wyższych kosztów personalnych w planie na kolejny rok i nie zagwarantował w ten sposób potrzebnego pokrycia finansowego $0^{53}$. Problemy z finansowaniem nie były już przedmiotem dalszej korespondencji ani raportów, więc prawdopodobnie udało się uzyskać pierwotnie przyznaną kwotę od Państwowej Komisji Planowania. Najważniejszym wskazywanym powodem niedotrzymania trzeciego terminu zdjęć były problemy z wyborem nowych odtwórców ról dziecięcych, a przede

${ }^{50}$ Do realizacji tego filmu przygodowego dla młodzieży w koprodukcji z zakładem Krátký film w okresie pomiędzy wznowieniem rozmów koprodukcyjnych rzeczywiście doszło.

${ }^{51}$ Protokół z narady ČST z zakładem Krátký film (niedat.), Archiwum Akt ČT, zespół Red, karton 247, nr i. 1728.

52 Załącznik do raportu z zagranicznej podróży służbowej, Archiwum Akt ČT, zespół Red, karton 247, nr i. 1728.

53 Raport z rozmów ČST i zakładu Krátký film dnia 6.02.1980, Archiwum Akt ČT, zespół Red, karton 247, nr i. 1728. 
wszystkim pogłębiający się kryzys polityczny w Polsce, którego wpływ na TVP był tak silny, że aneksy do umowy koprodukcyjnej nie mogły zostać rozpatrzone na poziomie kierownictwa produkcji, przez co nie mogły zostać na czas przyjęte ${ }^{54}$.

Pierwszy klaps serialu padł 17 marca, a główne zdjęcia zimowe musiały zostać przeniesione dopiero na początek 1982 roku. Jednak właśnie to odroczenie spowodowało kolejne i, jak się okazało, najpoważniejsze komplikacje - tuż przed rozpoczęciem zimowego etapu zdjęć w Polsce ogłoszono stan wojenny i cała polska ekipa została odwołana z planu. ČST postanowiła podejść do sytuacji operatywnie, aby nie doszło do kolejnego opóźnienia, także w związku z zakwaterowaniem w Karkonoszach. Polskich członków ekipy na stanowiskach, które nie były zdublowane, zastąpiła przez rozszerzenie ekipy czechosłowackiej, Kratký film otrzymał od ČST zamówienie na produkcję kostiumów i rekwizytów, które pozostały w Polsce. Najpierw realizowano ujęcia, które można było nakręcić z wykorzystaniem dublerów za nieobecnych polskich aktorów, natomiast detale były zaplanowane na później. Największą inwestycją była jednak konstrukcja dekoracji chaty Staszka w studiu filmowym, ponieważ jej oryginał pozostał niedostępny w Karpaczu po drugiej stronie granicy ${ }^{55}$.

Pomimo komplikacji serial udało się w roku 1982 dokończyć i wyemitować w okresie bożonarodzeniowym. W tym czasie budowane przez lata stosunki z Telewizją Polską znalazły się w punkcie zerowym - ekipy informacyjne i jakikolwiek import zostały sparaliżowane, a jedyną aktywność stanowiła wizyta redaktora naczelnego redakcji programów o państwach socjalistycznych L. ${ }^{56}$ Piotrowskiego, który przyjął pomoc oferowaną ze strony ČST i wybrał w Pradze nowe zaangażowane politycznie programy o tematyce roku 1968, a przede wszystkim późniejszego okresu konsolidacji ${ }^{57}$. Stosunki, które wcześniej znajdowały się tradycyjnie na ponadstandardowym poziomie $\mathrm{w}$ porównaniu $\mathrm{z}$ pozostałymi państwami socjalistycznymi, zostały naruszone przez rozległą restrukturalizację kierownictwa Telewizji Polskiej, które nie przejawiało silnej aktywności we wznawianiu stosunków międzynarodowych. W latach 1984 i 1985, w odróżnieniu od innych państw socjalistycznych, nie udało się osiągnąć

${ }^{54}$ List Zdeňka Bumby z działu zamówień Krátkého filmu do rąk Jaroslavy Kulišovej z dnia 4.01.1981, Archiwum Akt ČT, zespół Red, karton 247, nr i. 1728.

${ }_{55}$ Załącznik do dodatkowej propozycji produkcji filmu Długi biały ślad, Archiwum Akt ČT, zespół Red, karton 247, nr i. 1728.

${ }^{56}$ Imienia Piotrowskiego nie udało się odnaleźć w materiałach archiwalnych ani w innych dostępnych źródłach.

57 Raport o stosunkach zagranicznych ČST za rok 1982, Archiwum Akt ČT, zespół ZS, karton 163, nr i. 937. 
realizacji ani jednego programu polsko-czechosłowackiego ${ }^{58}$, a serial Dtugi biały ślad stanowi ostatnie wspólne przedsięwzięcie w dziedzinie twórczości dramatycznej. Pozostaje także końcowym memento świadczącym o ograniczeniach pełnowartościowej współpracy koprodukcyjnej między socjalistycznymi instytucjami telewizyjnymi. Spełnianie wyobrażeń o socjalistycznym internacjonalizmie, które wychodziłyby poza granice wymiany programowej i współpracy informacyjno-reporterskiej, napotykało trzy główne przeszkody: brak elastyczności organizacyjnej i dramaturgicznej, preferowanie wyłącznie stosunków opartych na wzajemności (motywowane ideologicznie oraz przez niedofinansowanie instytucji) oraz pragmatyczne względy ekonomiczne, które w ograniczonych warunkach skłaniały się ku niezbędnym zyskom dewizowym.

\section{Bibliografia}

\section{Archiwalia}

Archiwum Akt Telewizji Czeskiej.

\section{Druki zwarte}

Ostrowska Dorota, Radkiewicz Małgorzata, Costume dramas: cine-televisual alliances in the socialist and post-socialist Poland, [w:] European Cinemas in the Television Age, red. Dorota Ostrowska, Graham Roberts, Edinburgh University Press, Edinburgh 2007.

\section{Czasopisma}

Lederer Jiř́, Rubryka telewizyjna, „Filmové a televizní noviny 2" 24.01.1968, nr 2.

Nehodová Alena, Duhový Luk, „Československá televize” 1973, nr 17.

\section{Źródła internetowe}

Urbańska Gabriela, Historia polskiego filmu telewizyjnego, https://www.sfp.org.pl/2016/baza_ wiedzy,307,1487,0,1,Historia-polskiego-filmu-telewizyjnego.html (dostęp: 1.09.2017).

58 Raport o stosunkach zagranicznych ČST za rok 1983, Archiwum Akt ČT, zespół ZS, karton 163, nr i. 938; Raport o stosunkach zagranicznych ČST za rok 1982, Archiwum Akt ČT, zespół ZS, karton 163, nr i. 939. 


\section{Streszczenie}

Artykuł jest poświęcony rozwojowi współpracy i projektów koprodukcyjnych między Telewizją Czechosłowacką a Telewizją Polską w szerszym kontekście kontaktów twórczych między socjalistycznymi instytucjami telewizyjnymi. Autor wskazuje ograniczenia współpracy koprodukcyjnej w ramach państw bloku socjalistycznego, zwłaszcza w porównaniu z wyraźniejszym i ciągłym rozwojem koprodukcji z krajami zachodnimi. Przeszkodą było przede wszystkim oparcie współpracy na zasadzie wzajemności i idei socjalistycznego internacjonalizmu, przez co tłumione były interesy komercyjne. Pomimo naprzemiennych okresów umacniania i słabnięcia tych stosunków, współpraca Telewizji Czechosłowackiej z TVP stanowiła na tle kontaktów z innymi państwami wyjątek prowadzący do powstania pełnowartościowych projektów koprodukcyjnych: seriali Łuk tęczy i Długi biały ślad. W przypadku drugiego z seriali realizacja wspólnego przedsięwzięcia była w związku z wieloma przeszkodami bardzo problematyczna i tło jego powstania w sposób obrazowy świadczy o nienaturalnych warunkach socjalistycznej koprodukcji telewizyjnej. 